\title{
Apigenin induces apoptosis by suppressing Bcl-xl and Mcl-1 simultaneously via signal transducer and activator of transcription 3 signaling in colon cancer
}

\author{
YUZO MAEDA, HIROKI TAKAHASHI, NOZOMU NAKAI, TAKESHI YANAGITA, NANAKO ANDO, \\ TOMOTAKA OKUBO, KENTA SAITO, KAZUYOSHI SHIGA, TAKAHISA HIROKAWA, MASAYASU HARA, \\ HIDEYUKI ISHIGURO, YOICHI MATSUO and SHUJI TAKIGUCHI
}

\begin{abstract}
Department of Gastroenterological Surgery, Nagoya City University Graduate School of Medical Sciences, Nagoya, Aichi 467-8602, Japan
\end{abstract}

Received September 13, 2017; Accepted January 30, 2018

DOI: 10.3892/ijo.2018.4308

\begin{abstract}
Apigenin is a natural flavonoid that exhibits antiproliferative activity and induces apoptosis in various types of cancer, including colon cancer. The aim of the present study was to determine the mechanism underlying the apoptosisinducing effect of apigenin in colon cancer. Apigenin reduced the proliferation of colon cancer cell lines, stimulated the cleavage of PARP and induced apoptosis in a dose-dependent manner. Apigenin treatment also suppressed the expression of the anti-apoptotic proteins Bcl-xL and Mcl-1. Small interfering RNA was used to knockdown Bcl-xL and Mcl-1 expression alone and in concert, and the proliferation and apoptosis of cancer cells were subsequently measured. The knockdown of Bcl-xL and Mcl-1 expression together markedly suppressed cell proliferation and induced apoptosis. Apigenin treatment also inhibited the phosphorylation of signal transducer and activator of transcription 3 (STAT3), which targets Bcl-xL and Mcl-1. The results of the current study therefore determined that apigenin induces the apoptosis of colon cancer cells by inhibiting the phosphorylation of STAT3 and consequently downregulates the anti-apoptotic proteins Bcl-xL and Mcl-1.
\end{abstract}

\section{Introduction}

Colon cancer is the second leading cause of cancer-associated mortality in the United States (1). The current standard

Correspondence to: Dr Hiroki Takahashi, Department of Gastroenterological Surgery, Nagoya City University Graduate School of Medical Sciences, Kawasumi 1, Nagoya, Aichi 467-8602, Japan E-mail: takahasi@med.nagoya-cu.ac.jp

Abbreviations: DMSO, dimethyl sulfoxide; PARP,poly-(ADP-ribose) polymerase; STAT, signal transducer and activator of transcription.

Key words: apigenin, B-cell lymphoma-extra large, Mcl-1, signal transducer and activator of transcription 3, colon cancer, apoptosis treatment for patients with colon cancer is surgical resection followed by chemotherapy (2). However, patients that experience recurrence following surgery or are diagnosed when they are at an advanced stage colon cancer are difficult to treat, despite the development of novel chemotherapeutic regimens and molecular targeted therapy (3). In addition, continuous chemotherapy and molecular targeted therapy induce toxicity in normal tissues. Therefore, novel treatments are required that do not induce these problems in patients.

Apoptosis is a form of regulated cell death that results in the removal of damaged or potentially harmful cells (4). The Bcl-2 family of proteins consists of pro- (Bax and Bak) and anti-apoptotic proteins (Bcl-xL and $\mathrm{Mcl}-1)$ and they regulate apoptosis (5). Apoptosis is stimulated by the downregulation of anti-apoptotic proteins and/or the upregulation of proapoptotic proteins. Changes in the balance of these proteins promote the permeability of the outer membrane of mitochondria, resulting in the release of cytochrome $\mathrm{c}$ and the induction of apoptosis via the caspase cascade (6). Therefore, targeting the Bcl-2 family proteins, particularly the anti-apoptotic proteins, may be a novel method of treating cancer (7-10).

Apigenin is a common flavonoid and is present in many plants, fruits and vegetables, including oranges, onions, parsley, tea, chamomile, wheat sprouts and certain seasonings (11). One of the most common sources of consumed apigenin is chamomile tea, which is prepared from the dried flowers of Matricaria chamomilla (12). Apigenin possesses remarkable anti-inflammatory, -oxidant and -carcinogenic properties, and inhibits the proliferation, arrests the cell cycle and induces apoptosis in various types of cancer, including breast, lung, liver and ovarian cancer, without affecting healthy cells. It has been demonstrated that apigenin reduces the expression of Mcl-1 in colon cancer cells (13). However, to the best of our knowledge, the mechanism by which apigenin affects the Bcl-2 family of proteins in colon cancer remains unknown.

The signal transducer and activator of transcription (STAT) family consists of cytoplasmic transcription factors that form dimers upon phosphorylation, interact with other transcriptional modulators that migrate to the nucleus and bind to specific promoter sequences to induce gene expression (14). 
Several studies have demonstrated that STAT family proteins, including STAT3 and STAT5, recognize constitutive activity in different types of human cancer cells and stimulate the progression and development of human cancer $(15,16)$. Inhibition of STAT3 or STAT5 activation is associated with the suppression of cancer growth and the induction of cell death $(17,18)$. Previous studies have demonstrated that apigenin exhibits an antitumor effect in different types of cancer by inhibiting the STAT3 signaling pathway $(19,20)$. However, the effect of apigenin on the interaction between STAT signaling and the expression of Bcl-2 family proteins in colon cancer cells has not yet been investigated.

The present study demonstrated that apigenin induces the apoptosis of colon cancer cells by downregulating Bcl-xL and Mcl-1 expression via inhibition of the STAT signaling pathway. These results demonstrate that apigenin may be used as a novel therapeutic method of treating patients with colon cancer.

\section{Materials and methods}

Reagents. Antibodies against Bcl-xL (1:1,000, cat. no. 54H6), Mcl-1 (1:1,000, cat. no.D5V5L), STAT3 (1:1,000, cat. no. D3Z2G), phosphorylated (p)-STAT3 (1:2,000, cat. no. Tyr705), STAT5 (1:1,000, cat. no. D206Y), p-STAT5 (1:1,000, cat. no. Tyr694), poly-(ADP-ribose) polymerase (PARP; 1:1,000, cat. no. 46D11) and GAPDH (1:1,000, cat. no. 14C10) were purchased from Cell Signaling Technology, Inc. (Danvers, MA, USA). The secondary antibodies polyclonal goat anti-rabbit immunoglobulins (Igs) conjugated to horseradish peroxidase (HRP; 1:2,000, cat. no. P0448) and polyclonal goat anti-mouse Igs/HRP (1:2,000, cat. no. P0447) were purchased from Dako; Agilent Technologies, Inc. (Santa Clara, CA, USA). Apigenin (4',5,7-trihydroxyflavone) was purchased from R\&D Systems, Inc. (Minneapolis, MN, USA). Human recombinant interleukin-6 (IL-6) and human recombinant soluble IL-6 receptor were purchased from PeproTech, Inc. (Rocky Hill, NJ, USA). IL-6 was used supplemented with soluble IL-6 receptor $(40 \mathrm{ng} / \mathrm{ml})$.

Cell culture. The human colon cancer cell lines HT29, DLD-1, COLO320 and HCT116 were obtained from the American Type Culture Collection (Manassas, VA, USA). HT29 (KRAS wild-type) cells were cultured in Dulbecco's modified Eagle's medium (Sigma-Aldrich; Merck KGaA, Darmstadt, Germany) supplemented with $10 \%$ fetal bovine serum (FBS; Thermo Fisher Scientific, Inc., Waltham, MA, USA) and 1\% antibiotic-antimycotic (Sigma-Aldrich; Merck KGaA). DLD-1 (KRAS mutant-type) and COLO320 (KRAS wild-type) cells were cultured in RPMI-1640 medium (Sigma-Aldrich; Merck KGaA) supplemented with $10 \%$ FBS and $1 \%$ antibioticantimycotic. HCT116 (KRAS mutant-type) cells were cultured in McCoy's 5A medium (Thermo Fisher Scientific, Inc.) supplemented with $10 \%$ FBS and $1 \%$ antibiotic-antimycotic. All cell lines were maintained at $37^{\circ} \mathrm{C}$ in a humidified incubator containing $5 \% \mathrm{CO}_{2}$.

Patients and tumor samples. Colon cancer tissue samples were obtained from 40 patients ( 25 males and 15 females) with Stage IV colon cancer who had undergo surgery at the Nagoya City University Hospital (Nagoya, Japan) between January 2012 and December 2014. Resected specimens were staged by pathological evaluation according to the Japanese Classification of Colorectal Carcinoma (21). The mean age of the patients was $66.2 \pm 10$ years (range, $37-88$ years). All patients gave their written informed consent for the use of their tissue samples in the present study.

Immunohistochemistry. Resected specimens were fixed with formalin at room temperature for 2 days. Formalin-fixed, paraffin-embedded sections $4-\mu \mathrm{m}$-thick were deparaffinized in xylene and hydrated in graded alcohols. Following washing with running water, samples were soaked in soak in $10 \mathrm{mM}$ citric acid buffer $(9 \mathrm{ml} 0.1 \mathrm{M}$ citric acid $+41 \mathrm{ml} 0.1 \mathrm{mM}$ trisodium citrate dihydrate $+450 \mathrm{ml}$ distilled water) and boiled for $10 \mathrm{~min}$. Following 3 washes with PBS ( $5 \mathrm{~min} / \mathrm{time}$ ) the slide was immersed in a mixture of $1.5 \mathrm{ml} 30 \%$ hydrogen peroxide solution and $150 \mathrm{ml} 100 \%$ methanol for $30 \mathrm{~min}$ to block endogenous peroxidase. Following washing with PBS, slides were blocked with $400 \mu 14 \%$ Block Ace ${ }^{\circledR}$ Powder (cat. no. UK-B80; DS Pharma Biomedical Co., Ltd., Osaka, Japan) for $10 \mathrm{~min}$ in a humidity box at room temperature. Subsequently, slides were incubated with primary antibodies against Bcl-xL (1:300) and Mcl-1 (1:100) onto at $4^{\circ} \mathrm{C}$ overnight. Following washing with PBS, slides were incubated with $100 \mu 1$ secondary antibody (EnVision + Single Reagents HRP; cat. no. K4003; Dako; Agilent Technologies, Inc.) for $45 \mathrm{~min}$ at room temperature. The detection step was performed using Liquid DAB + Substrate Chromogen System (cat. no. K3467; Dako; Agilent Technologies, Inc.) for $10 \mathrm{~min}$ at room temperature and the sections were counterstained with hematoxylin for $30 \mathrm{sec}$ at room tenmperature. Slides were analyzed using a light microscope (magnification, $\mathrm{x} 400$ ). Ethical approval for the use of human tissue was granted by the Graduate School of Medicine, Nagoya City University (Nagoya, Japan) and all patients provided their informed consent for the use of their tissues in the current study.

Preparation of apigenin. Apigenin was dissolved in dimethyl sulfoxide (DMSO; Wako Chemicals GmbH, Neuss, Germany) to produce $50 \mathrm{mM}$ stock solutions that were aliquoted and stored at $-28^{\circ} \mathrm{C}$ prior to use. Stock solutions were diluted with culture medium to the indicated concentrations (final DMSO concentration, $0.1 \%$ ).

Transfection of small interfering (si)RNA. Bcl-xL siRNA (5 nM, ID\#:s1922; forward, 5'-GGAACUCUAUGGGAACAAUTT-3' and reverse, 5'-AUUGUUCCCAUAGAGUUCCAC-3'), Mcl-1 siRNA (5 nM, ID\#:s8583; forward, 5'-CCAGUAUACUUCUU AGAAATT-3' and reverse, 5'-UUUCUAAGAAGUAUACUG GGA-3'), negative control siRNA (5 nM, cat. no. 4390843 , Silencer Select Negative Control \#1) and STAT3 siRNA (5 nM, ID\#:s744, sequence: forward, 5'-GGCUGGACAAUAUCAUU GATT-3' and reverse, 5'-UCAAUGAUAUUGUCCAGCCAG-3') were purchased from Thermo Fisher Scientific, Inc. On the day before siRNA transfection, DLD-1 and HCT116 cells $\left(1.0 \times 10^{4}\right.$ cells) were seeded to $60-80 \%$ confluence in their respective growth mediums without antibiotics. siRNAs and Lipofectamine RNAiMAX were diluted in Opti-MEM medium (both from Thermo Fisher Scientific, Inc.), mixed gently and incubated for 10-20 min at room temperature. Cells were transfected by adding the siRNA-Lipofectamine RNAiMAX complex 
dropwise to the medium to achieve a siRNA final concentration of $100 \mathrm{nM}$. Cells were incubated at $37^{\circ} \mathrm{C}$ in a $\mathrm{CO}_{2}$ incubator and knockdown efficiency was evaluated $24 \mathrm{~h}$ post-transfection.

DNA fragmentation assay. Cells (5x10 $/$ well) were seeded into 6-well culture plates and incubated at $37^{\circ} \mathrm{C}$ overnight. Medium was replenished with serum-free medium and incubated for a further $4 \mathrm{~h}$. Cells were then treated with apigenin at various doses $0,5,15$ and $50 \mu \mathrm{M}$ or transfected to target Bcl-xL, Mcl-1 or Bcl-xL and Mcl-1 together. DNA fragmentation was analyzed using a Cell Death Detection ELISA ${ }^{\text {Plus }}$ kit (Sigma-Aldrich; Merck KGaA) following the manufacturer's protocol. The degree of apoptosis was evaluated using an enrichment factor ( $\mathrm{mU}$ of treated cells/mU of non-treated cells).

Cell proliferation assay. The effect of apigenin or siRNA on cell proliferation was measured using WST-1 and BrdU assays. Each assay was performed at least three times. The WST-1 assay was performed using a Premix WST-1 cell proliferation assay system (Takara Bio, Inc., Tokyo, Japan). Cells $\left(5 \times 10^{3}-5 \times 10^{4} /\right.$ well) were seeded into 96 -well tissue culture plates and incubated at $37^{\circ} \mathrm{C}$ overnight. Cells were treated with $0,5,15$ and $50 \mu \mathrm{M}$ apigenin or transfected to target $\mathrm{Bcl}-\mathrm{xL}$, Mcl-1 or Bcl-xL and Mcl-1 together in serum-free medium. After $48 \mathrm{~h}$, the medium was removed and replaced with fresh medium (90 $\mu \mathrm{l} /$ well) containing Premix WST-1 (10 $\mu \mathrm{l} /$ well). Cells were then incubated at $37^{\circ} \mathrm{C}$ for $2 \mathrm{~h}$. Absorbance was measured using a plate reader at $450 \mathrm{~nm}$. The BrdU assay was performed using BrdU Cell Proliferation ELISA kit (colorimetric; cat. no. ab126556; Abcam, Cambridge, MA, USA), following the manufacturer's protocol. Cells $\left(5 \times 10^{3}-5 \times 10^{4} /\right.$ well $)$ were seeded into 96-well tissue culture plates and incubated at $37^{\circ} \mathrm{C}$ overnight. Cells were treated with $0,5,15$ and $50 \mu \mathrm{M}$ apigenin or transfected to target Bcl-xL, Mcl-1, or Bcl-xL and $\mathrm{Mcl}-1$ together in serum-free medium for $32 \mathrm{~h}$ at $37^{\circ} \mathrm{C}$. A total of $20 \mu \mathrm{l} 1 / 500$ diluted BrdU was added and incubated for $16 \mathrm{~h}$ at room temperature. Subsequently, fixing solution was added for $30 \mathrm{~min}$ at room temperature to fix and permeabilize cells, and denature the DNA. Subsequently, anti-BrdU antibody was added to each well for $1 \mathrm{~h}$ and peroxidase-conjugated goat anti-mouse immunoglobulin $\mathrm{G}$ antibody was added for $30 \mathrm{~min}$. Incubation with primary and secondary antibodies was performed at room temperature. Finally, 3,3',5,5'-tetramethylbenzidine peroxidase substrate was added to each well and following incubation in the dark for $30 \mathrm{~min}$, stop solution was added to each well. Absorbance was measured at $450 \mathrm{~nm}$ using a microplate reader.

Identifying the mechanism of action of apigenin. Western blotting was performed to identify the mechanism of action of apigenin. Cells (DLD-1, HCT116: 1×10\% /dish) were seeded in 4 dishes and incubated at $37^{\circ} \mathrm{C}$ overnight. The following day, cells were treated with $0,5,15$ and $50 \mu \mathrm{M}$ IL-6 in serum-free medium for $48 \mathrm{~h}$. Proteins were the extracted and expression of p-STAT3 was evaluated by western blotting.

Cells (DLD-1, HCT116: 1×10\% 4 dishes and incubated at $37^{\circ} \mathrm{C}$ overnight. The following day, cells were treated with or without $50 \mu \mathrm{M}$ (DLD-1), $15 \mu \mathrm{M}$ (HCT 116) apigenin for $2 \mathrm{~h}$ and then with or without $50 \mu \mathrm{M}$ IL- 6 for a further $48 \mathrm{~h}$. Proteins were extracted and expression of p-STAT3, Bcl-xL and Mcl-1 was evaluated by western blotting.

Western blot analysis. Protein samples were prepared in radioimmunoprecipitation lysis buffer with Protease Inhibitor Single Use Cocktail and Phosphatase Inhibitor Cocktail (all from Thermo Fisher Scientific, Inc.). Protein concentrations were measured using a BCA protein assay kit (Thermo Fisher Scientific, Inc.). Equal amounts of protein extract were denatured by boiling at $90^{\circ} \mathrm{C}$ for $5 \mathrm{~min}$. Proteins $(20 \mu \mathrm{g})$ were fractionated on 4-15\% Mini-PROTEAN TGX gels and transferred to nitrocellulose membranes (both from Bio-Rad Laboratories, Inc., Hercules, CA, USA). The primary and secondary antibody reactions were performed using an iBind Flex Western System (Thermo Fisher Scientific, Inc.). Membranes were incubated with iBind Flex Solution (iBind Flex Buffer, iBind Flex Additive and distilled water) for $10 \mathrm{~min}$ at room temperature to block nonspecific binding. Primary (Bcl-xL, Mcl-1, STAT3, p-STAT3, STAT5, p-STAT5, PARP and GAPDH) and secondary (polyclonal goat anti-rabbit IGs conjugated to HRP) antibody reactions were performed at room temperature for $2.5 \mathrm{~h}$, following the manufacturer's protocol. Protein-antibody complexes were visualized using SuperSignal West Pico Chemiluminescent Substrate or SuperSignal West Femto Chemiluminescent Substrate (Thermo Fisher Scientific, Inc.). The immunoreactive protein band was detected and band density was quantified by densitometry using an Amersham Imager 600 (GE Healthcare Life Sciences, Little Chalfont, UK).

Statistical analysis. All statistical analyses were performed using EZR software (Easy R) version 1.27 (Saitama Medical Center, Jichi Medical University, Saitama, Japan). All data are presented as the mean \pm standard deviation. Statistical comparisons with paired observations were determined using the Student's t-test. Comparisons of more than two groups were made by a one-way analysis of variance followed by Dunnett's test. $\mathrm{P}<0.05$ was considered to indicate a statistically significant difference.

\section{Results}

Apigenin reduces the proliferation of colon cancer cells. To investigate whether apigenin inhibits the proliferation of colon cancer cells, four colon cancer cell lines (HT29, DLD-1, COLO320 and HCT116) were treated with 0, 5, 15 and $50 \mu \mathrm{M}$ apigenin for $48 \mathrm{~h}$. Cell proliferation was measured using WST-1 (Fig. 1A) and BrdU (Fig. 1B) assays. The results demonstrated that apigenin significantly reduced the proliferation of all four colon cancer cell lines in a dose-dependent manner.

Apigenin induces apoptosis in colon cancer cells via a caspasedependent pathway. To investigate whether the inhibition of cell proliferation by apigenin was due to the induction of apoptosis, four colon cancer cell lines were exposed to various doses of apigenin for $24 \mathrm{~h}$ and the degree of DNA fragmentation in the cells was then measured. The results demonstrated that apigenin induced DNA fragmentation in a dose-dependent manner in all four colon cancer cell lines (Fig. 2A). 

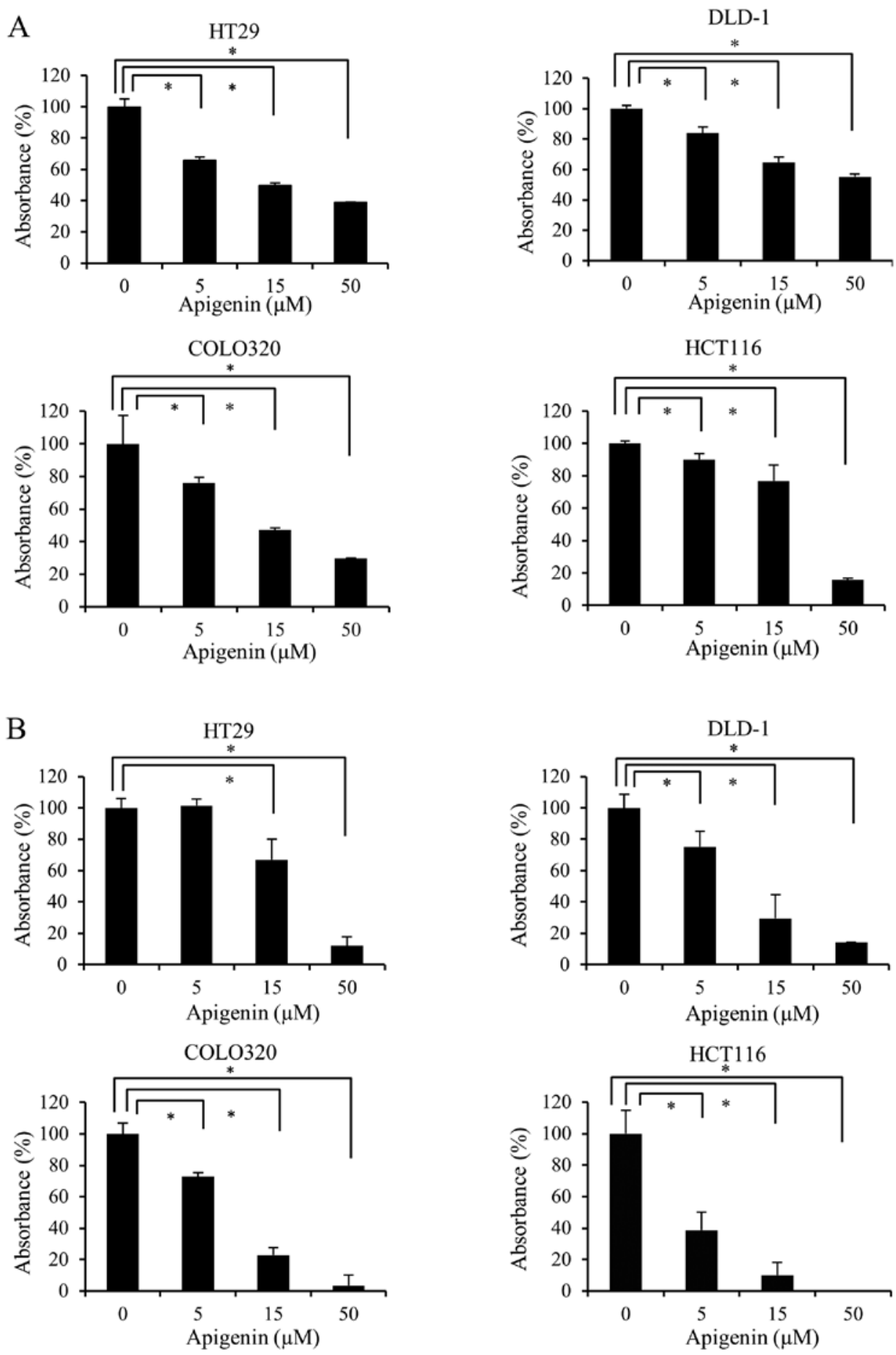

Figure 1. The effect of apigenin on the proliferation of colon cancer cells. Proliferation was measured using (A) WST-1 and a (B) BrdU assays. Four human colon cancer cell lines were treated with $0,5,15$ or $50 \mu \mathrm{M}$ apigenin for $48 \mathrm{~h}$. Results are representative of three independent experiments and are presented as the mean \pm standard deviation. ${ }^{*} \mathrm{P}<0.05$.

Subsequently, it was determined whether the effect of apigenin on apoptosis was mediated by caspase activation. The four colon cancer cell lines were treated with various doses of apigenin for $24 \mathrm{~h}$ and the cleavage of PARP was evaluated by western blotting. The results demonstrated that apigenin induced the cleavage of PARP in a dose-dependent manner (Fig. 2B). In HCT116 cells, the apoptosis-inducing effect of $50 \mu \mathrm{M}$ apigenin was weaker than that of $15 \mu \mathrm{M}$ apigenin. However, as presented in Fig. 1, the suppression of cell proliferation in HCT116 occurred in a dose-dependent manner, with $50 \mu \mathrm{M}$ apigenin inducing the most marked inhibition. Thus, it was considered that this phenomenon may involve other processes, as well as apoptosis, such as necrosis. Therefore, only 5 and $15 \mu \mathrm{M}$ apigenin were used to treat HCT116 cells in subsequent experiments investigating the effects of apigenin on the apoptosis of colon cancer cells.

Apigenin downregulates the expression of the anti-apoptotic Bcl-2 family members Bcl-xL and Mcl-1. The anti-apoptotic Bcl-2 family of proteins serves an important role in protecting 
A
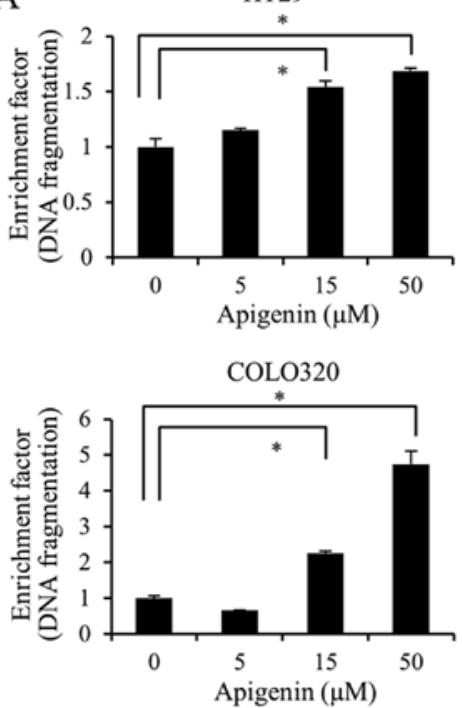

B

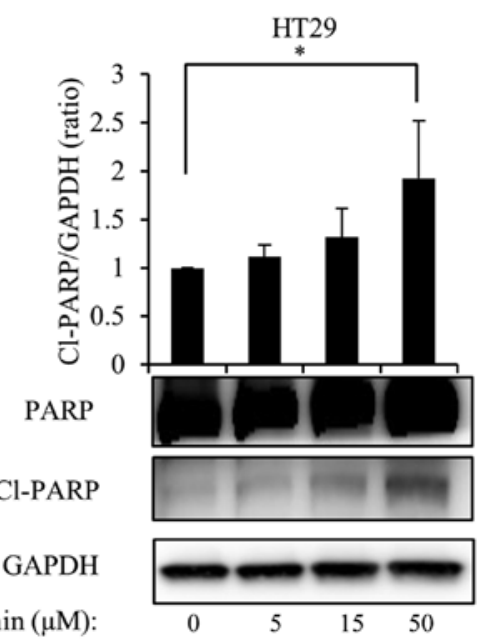

Apigenin $(\mu \mathrm{M})$ :

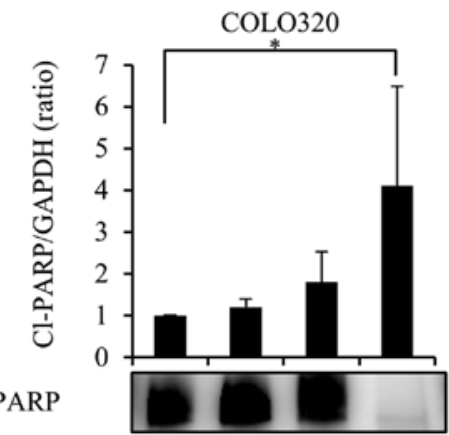

Cl-PARP

GAPDH

Apigenin $(\mu \mathrm{M})$ :

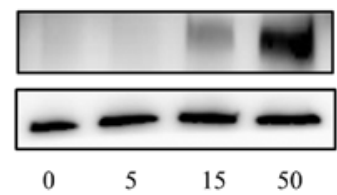

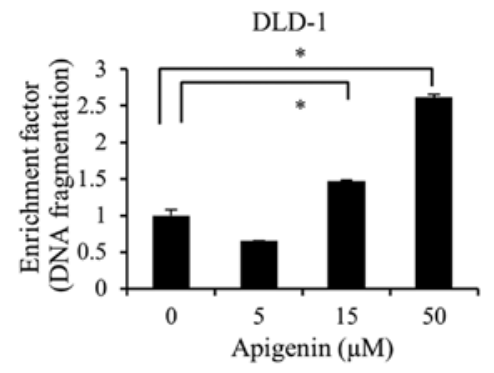
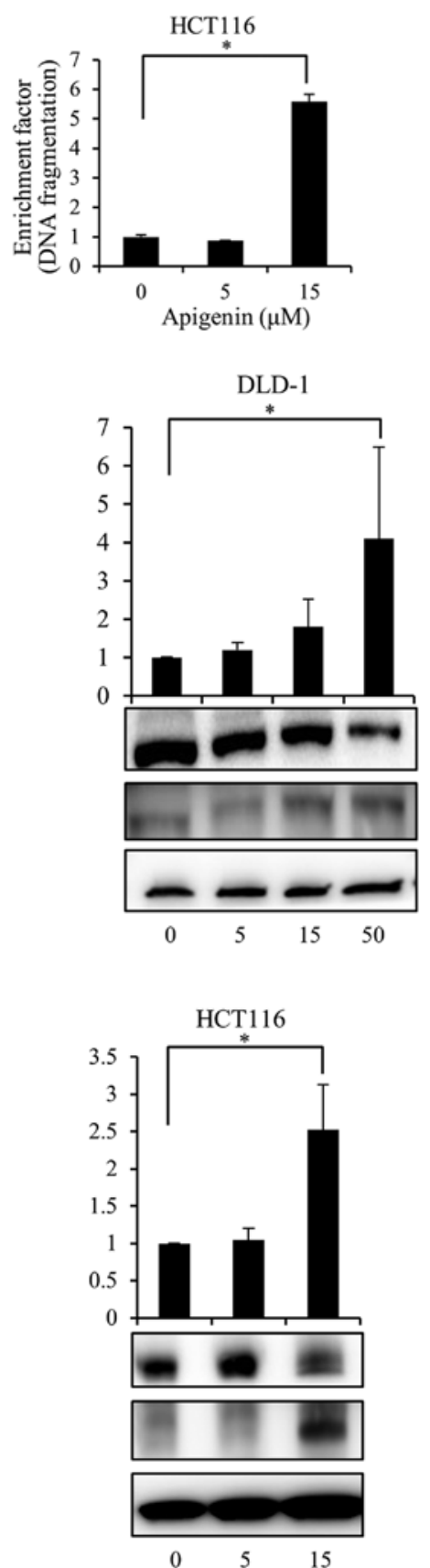

Figure 2. The effect of apigenin on the apoptosis of colon cancer cells. (A) Cells were treated with 5,15 or $50 \mu \mathrm{M}$ apigenin for $24 \mathrm{~h}$. The extent of apoptosis was analyzed using a cell death ELISA kit and evaluated with enrichment factor to assess DNA fragmentation. Results are representative of three independent experiments and are presented as the mean \pm standard deviation. ${ }^{*} \mathrm{P}<0.05$. (B) Cells were treated with 5 , 15 or $50 \mu \mathrm{M}$ apigenin for $24 \mathrm{~h}$. The expression of Cl-PARP was evaluated by western blotting. Band density was quantified by densitometry using an Amersham Imager 600 and were expressed as Cl-PARP/GAPDH. GAPDH was used as a loading control. Results are representative of three independent experiments and are presented as the mean \pm standard deviation. ${ }^{*} \mathrm{P}<0.05$. $\mathrm{Cl}$, cleaved; PARP, poly-(ADP-ribose) polymerase.

against DNA damage-induced apoptosis. Therefore, the present study investigated the effect of apigenin on the expression of anti-apoptotic Bcl-2 family proteins. The four colon cancer cell lines were exposed to various doses of apigenin for $24 \mathrm{~h}$ and 

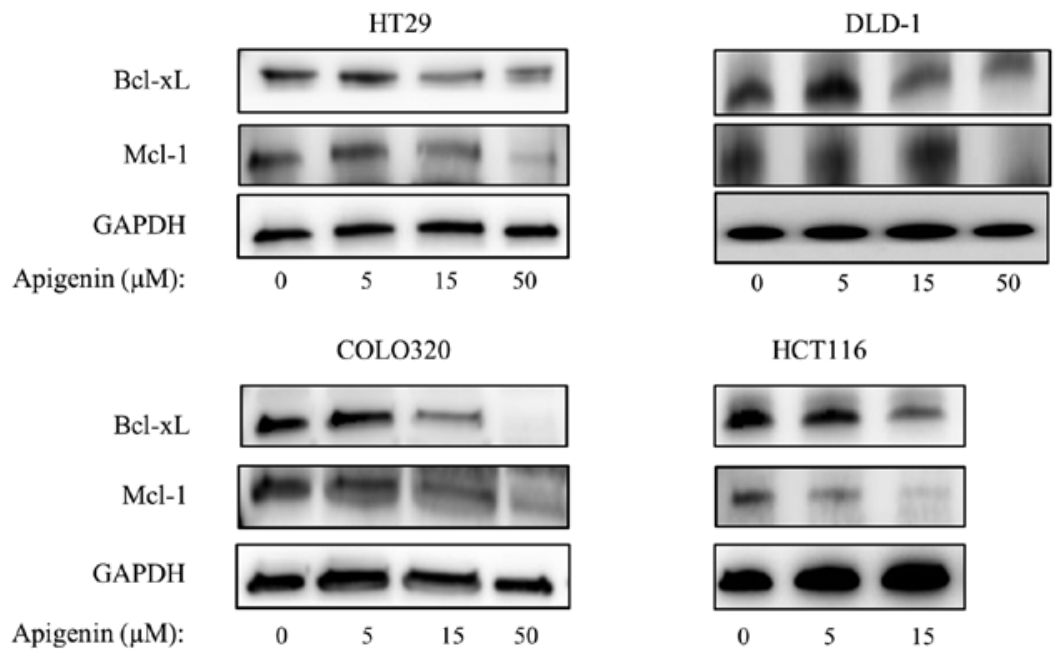

HCT116

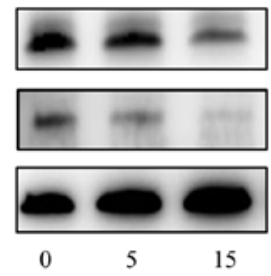

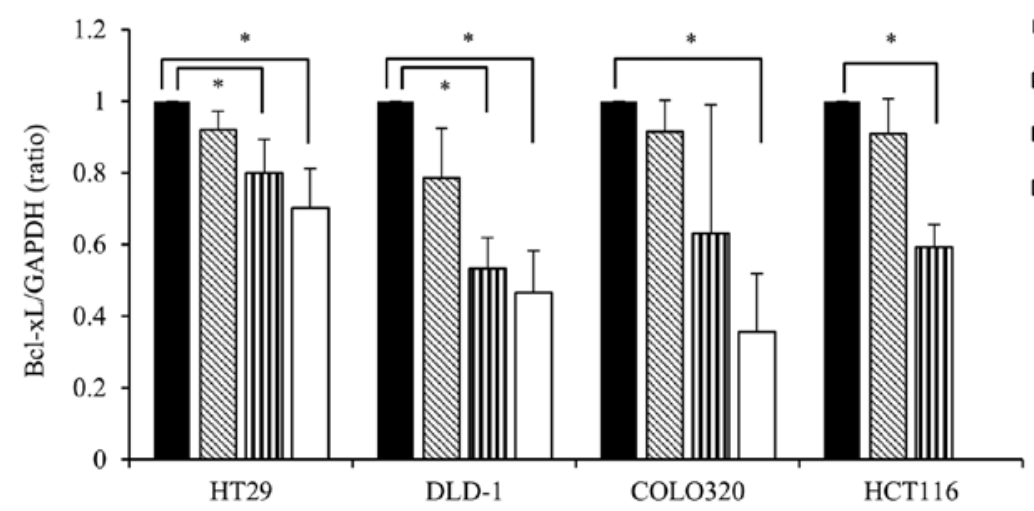

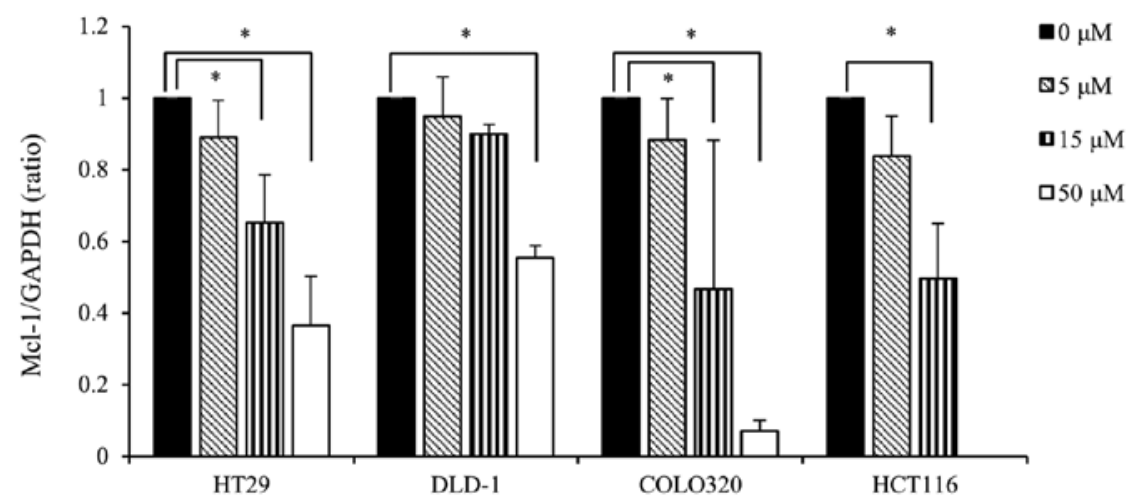

Figure 3. The effect of apigenin on the expression of the anti-apoptotic proteins Bcl-xL and Mcl-1. Cells were treated with 5,15 or $50 \mu \mathrm{M}$ apigenin for $24 \mathrm{~h}$. Changes in the expression of Bcl-xL and Mcl-1 were evaluated by western blotting. The density of bands was quantified by densitometry using Amersham Imager 600 and were expressed as Bcl-xL/GAPDH and Mcl-1/GAPDH. GAPDH was used as a loading control. Results are representative of three independent experiments and are presented as the mean \pm standard deviation. ${ }^{*} \mathrm{P}<0.05$.

the expression of Bcl-xL and Mcl-1 were measured by western blotting. The results demonstrated that apigenin significantly downregulated the expression of $\mathrm{Bcl}-\mathrm{xL}$ and $\mathrm{Mcl}-1$ in all colon cancer cells lines in a dose-dependent manner (Fig. 3).

The simultaneous downregulation of Bcl-xL and Mcl-1 strongly induces apoptosis via a caspase-dependent pathway in colon cancer cells. Apigenin downregulated the expression of Bcl-xL and Mcl-1; therefore, it was hypothesized that the anti-apoptotic Bcl-2 family proteins Bcl-xL and Mcl-1 are involved in apigenin-induced apoptosis. To determine whether this was the case, the DLD-1 and HCT116 cell lines were used.
As a preliminary experiment, immunostaining of clinical specimens of colon cancer was performed. The results demonstrated that expression of Bcl-xL was very strong in colon cancer and that the expression of Mcl-1 was relatively weak (data not presented). Since these data were in accordance with the results of western blotting regarding Bcl-xL and Mcl-1 expression in the DLD-1 and HCT116 cell lines, the following experiments were performed on these two cell lines.

Cells were transfected with siRNA targeting Bcl-xL, Mcl-1, or Bcl-xL and Mcl-1 together. Transfection with the siRNAs downregulated Bcl-xL and MCl-1 expression in DLD-1 and HCT116 cells (Fig. 4A). To investigate whether transfection 
A Bcl-xL
Mcl-1
GAPDH
Control-si:
Bcl-xL-si:
Mcl-1-si:

B

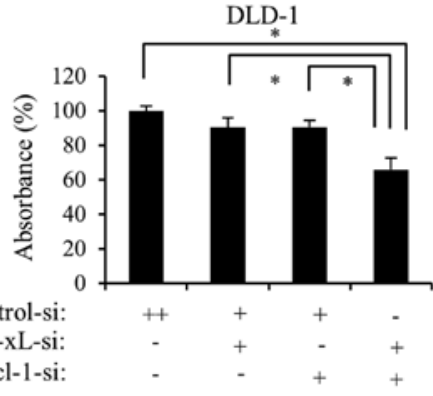

$\mathrm{C}$

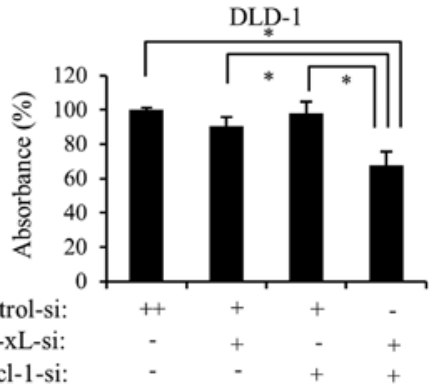

$\mathrm{D}$

E
HCT116

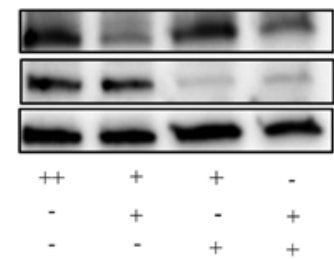

HCT116
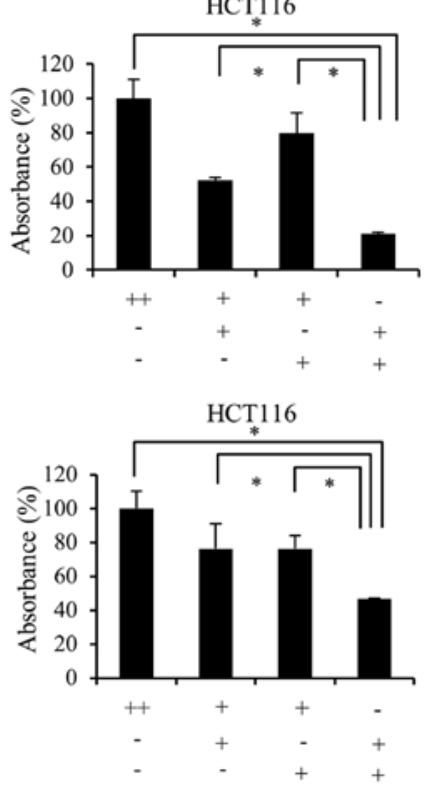

DLD-1
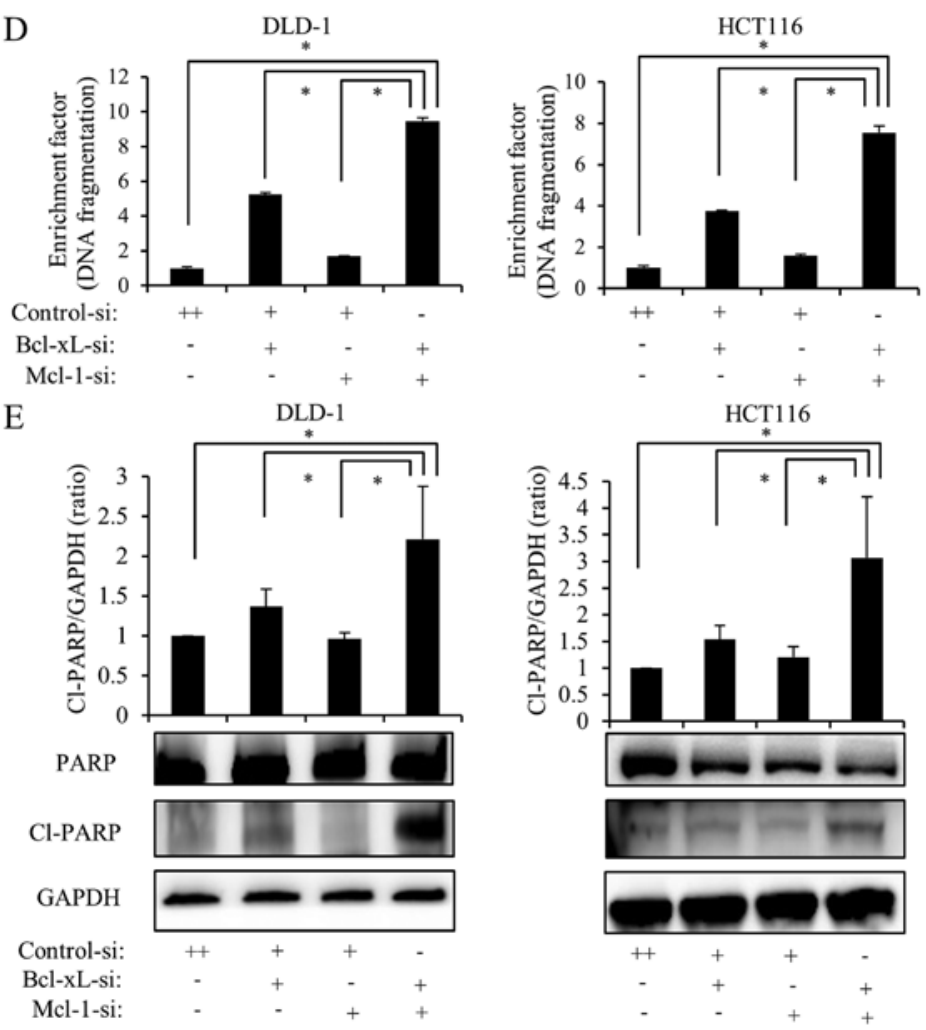

Figure 4. The simultaneous downregulation of Bcl-xL and Mcl-1 reduces cell proliferation and induces apoptosis via the caspase cascade in colon cancer cells. (A) DLD-1 and HCT116 were transfected with siRNA targeting Bcl-xL, Mcl-1 or Bcl-xL and Mcl-1 together for $24 \mathrm{~h}$. Levels of Bcl-xL and Mcl-1 were measured using western blotting. (B) DLD-1 and HCT116 were transfected with siRNA targeting Bcl-xL, Mcl-1 or Bcl-xL and Mcl-1 together for $48 \mathrm{~h}$. Cell proliferation was measured using a WST-1 assay. (C) DLD-1 and HCT116 cells were transfected with siRNA targeting Bcl-xL, Mcl-1 or Bcl-xL and Mcl-1 together for 48 h. Cell proliferation was measured using the BrdU assay. (D) DLD-1 and HCT116 were transfected with siRNA targeting Bcl-xL, Mcl-1 or Bcl-xL and Mcl-1 together for $24 \mathrm{~h}$. The extent of apoptosis was evaluated by assessing DNA fragmentation. (E) DLD-1 and HCT116 were transfected with siRNA targeting Bcl-xL, Mcl-1 or Bcl-xL and Mcl-1 together for $24 \mathrm{~h}$ and then levels of PARP and Cl-PARP were measured by western blotting. Band densities were quantified via densitometry using the Amersham Imager 600 and were expressed as Cl-PARP/GAPDH. GAPDH was used as a loading control. Results are representative of three independent experiments and are presented as the mean \pm standard deviation. " $\mathrm{P}<0.05$. Cl, cleaved; PARP, poly-(ADP-ribose) polymerase; si, small interfering. 
with siRNA inhibits colon cancer cell proliferation, DLD-1 and HCT116 cells were transfected with siRNA targeting Bcl-xL, Mcl-1, or Bcl-xL and Mcl-1 together for 48 h. Cell proliferation was measured using WST-1 (Fig. 4B) and BrdU assays (Fig. 4C). Downregulation of Bcl-xL alone or Mcl-1 alone reduced cell proliferation. However, the simultaneous downregulation of $\mathrm{Bcl}-\mathrm{xL}$ and $\mathrm{Mcl}-1$ significantly reduced the proliferation of the two cell lines.

Subsequently, it was determined whether transfection with siRNA induces apoptosis in colon cancer cells. DLD-1 and HCT116 cells were transfected with siRNA targeting Bcl-xL, Mcl-1, or Bcl-xL and Mcl-1 together for $24 \mathrm{~h}$. Subsequently, the degree of DNA fragmentation in the cells was measured. Downregulation of Bcl-xL or Mcl-1 alone induced DNA fragmentation in DLD-1 and HCT116 cells. However, the simultaneous downregulation of Bcl-xL and Mcl-1 significantly induced DNA fragmentation (Fig. 4D).

Subsequently, it was determined whether the effect of the simultaneous downregulation of Bcl-xL and Mcl-1 on apoptosis was mediated by the activation of caspases. DLD-1 and HCT116 cells were transfected with siRNA targeting Bcl-xL, Mcl-1 or Bcl-xL and Mcl-1 together for $24 \mathrm{~h}$ and the degree of PARP cleavage was evaluated using western blotting. Downregulation of $\mathrm{Bcl}-\mathrm{xL}$ or $\mathrm{Mcl}-1$ alone slightly increased the cleavage of PARP in DLD-1 and HCT116 cells. However, the simultaneous downregulation of Bcl-xL and $\mathrm{Mcl}-1$ significantly increased the cleavage of PARP in the two cell lines (Fig. 4E), which was consistent with the results of the cell proliferation and DNA fragmentation studies. These results suggest that the simultaneous downregulation of Bcl-xL and Mcl-1 strongly induces the apoptosis of colon cancer cells.

Apigenin reduces constitutive STAT3 phosphorylation and siRNA targeting STAT3 downregulates the expression of $B c l-x L$ and $M c l-1$. To further investigate the mechanism by which apigenin induces apoptosis, the effect of apigenin on the expression of p-STAT3 and STAT5 in DLD-1 and HCT116 cells was investigated. DLD-1 and HCT116 cells were exposed to various doses of apigenin for $24 \mathrm{~h}$, then the expression of p-STAT3, p-STAT5 and total STAT3, STAT5 were measured by western blotting. Levels of p-STAT3 significantly decreased in a dose-dependent manner; however, apigenin treatment did not affect the total amount of STAT3 expression (Fig. 5A). Furthermore, apigenin did not affect the expression of p- and total STAT5 (Fig. 5B). Subsequently, it was determined whether Bcl-xL and Mcl-1 were downregulated by STAT3 knockdown. DLD-1 and HCT116 cells were transfected with siRNA targeting STAT3 for $24 \mathrm{~h}$ and subsequently the expression of Bcl-xL and Mcl-1 were measured using western blotting. The results demonstrated that levels of Bcl-xL and Mcl-1 were significantly downregulated in DLD-1 and HCT116 cells following transfection with siSTAT3 (Fig. 5C).

Apigenin suppresses $B c l-x L / M c l-1$ via STAT3 signaling. It has been reported that IL-6 leads to STAT3 phosphorylation by activating janus kinase (22). DLD-1 and HCT116 cell lines were administered various doses of IL-6 for $48 \mathrm{~h}$ and the expression of p-STAT3 was measured using western blotting. The results indicated that p-STAT3 expression increased in a dose-dependent manner following treatment with IL-6 (Fig. 6A). Subsequently, $50 \mu \mathrm{M}$ IL-6 was administered to cells $2 \mathrm{~h}$ following treatment with apigenin. After $48 \mathrm{~h}$, levels of p-STAT3, Bcl-xL and Mcl-1 were measured and it was demonstrated that the expression of p-STAT3, Bcl-xL and Mcl-1 significantly increased following stimulation with IL-6; however, this increase was almost completely reversed following administration of apigenin (Fig. 6B). Therefore, it was suggested that apigenin suppresses the expression of Bcl-xL and Mcl-1 via STAT3 signaling (Fig. 6C).

\section{Discussion}

The results of the current study demonstrated that the natural dietary flavonoid, apigenin, reduces proliferation and induces apoptosis in colon cancer cells. It was also demonstrated that apigenin induces apoptosis by suppressing Bcl-xL and $\mathrm{Mcl}-1$ and that apigenin downregulated Bcl-xL and Mcl-1 by inhibiting the phosphorylation of STAT3.

Apigenin is found in many fruits and vegetables and is one of the most bioactive flavonoids (12). Apigenin exhibits low cytotoxicity and has a marked effect on cancer cells compared with normal cells (23). It has been reported that apigenin reduces cell proliferation and induces apoptosis in colon cancer cells (24-26). However, the detailed mechanism of apigenin-induced apoptosis of colon cancer cells remains unknown. Therefore, the molecular mechanism by which apigenin induces apoptosis in colon cancer cells was assessed in the current study.

The results demonstrated that the apoptosis inducing effect of apigenin is mediated via the caspase cascade; therefore, it was postulated that the anti-apoptotic Bcl-2 family proteins are involved in the apoptosis-inducing effect of apigenin. Apigenin suppressed the expression of Bcl-xL and Mcl-1 in all four colon cancer cell lines. Previous studies demonstrated that apigenin suppresses the expression of various anti-apoptotic Bcl-2 family proteins, including Bcl-xL, Mcl-1 and Bcl-2 in several cancer cell lines $(27,28)$. However, it has only been demonstrated that apigenin suppresses Bcl-xL and Mcl-1 in bladder cancer and multiple myeloma cell lines $(29,30)$. To the best of our knowledge, the current study is the first to report that apigenin suppresses the expression of Bcl-xL and Mcl-1 in colon cancer cells. Shao et al (13) reported that apigenin reduces $\mathrm{Mcl}-1$ expression and sensitizes the $\mathrm{Bcl}-2$ homology domain 3 mimetic ABT-263. These results are similar to those of the current study, although they did not measure Bcl-xL expression. The results of present study demonstrated that apigenin simultaneously reduces Bcl-xL and Mcl-1 expression and strongly induces apoptosis in colon cancer cells, suggesting that apigenin itself exhibits strong antitumor activity in colon cancer cells.

The anti-apoptotic Bcl-2 family of proteins serve a protective role against various apoptotic stimuli (31). The overexpression of anti-apoptotic Bcl-2 family proteins, including $\mathrm{Bcl}-\mathrm{xL}$ and $\mathrm{Mcl}-1$, is observed in different types of human cancer and this overexpression is involved in the development of resistance to treatments such as chemotherapy, as well as in cell survival $(32,33)$. In the present study, the overexpression of Bcl-xL and Mcl-1 was observed in four colon cancer cell lines. Therefore, these proteins may be effective therapeutic targets 
A
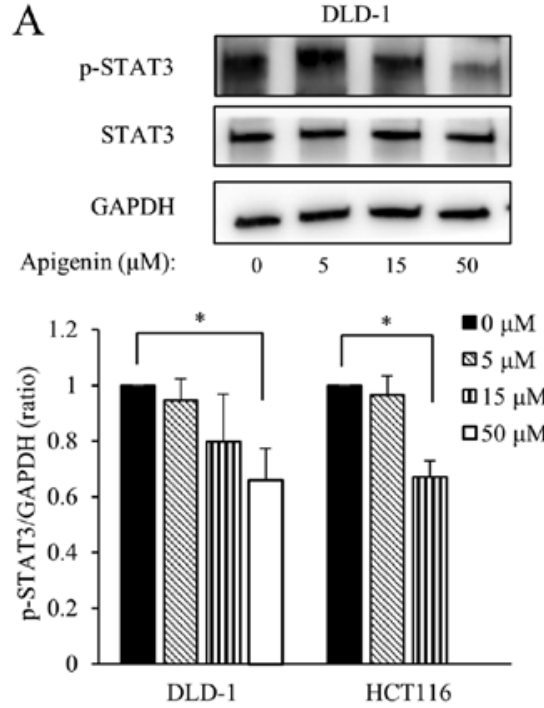

B

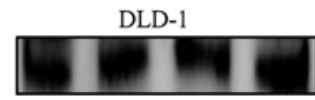

STAT5

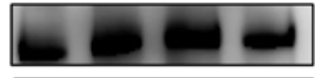

GAPDH

Apigenin $(\mu \mathrm{M})$ :
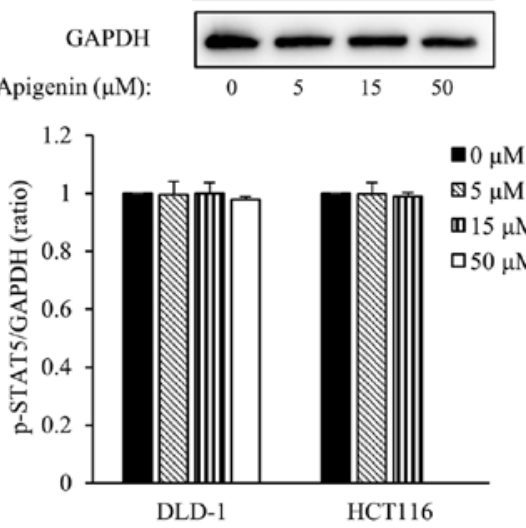

C
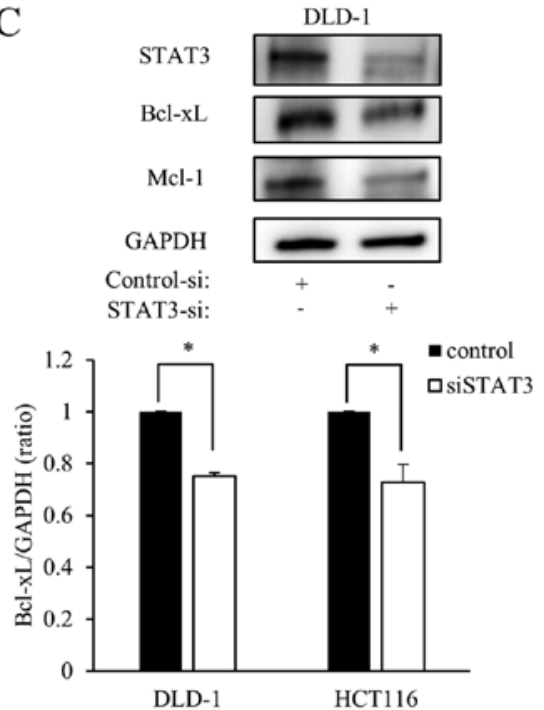

HCT 116
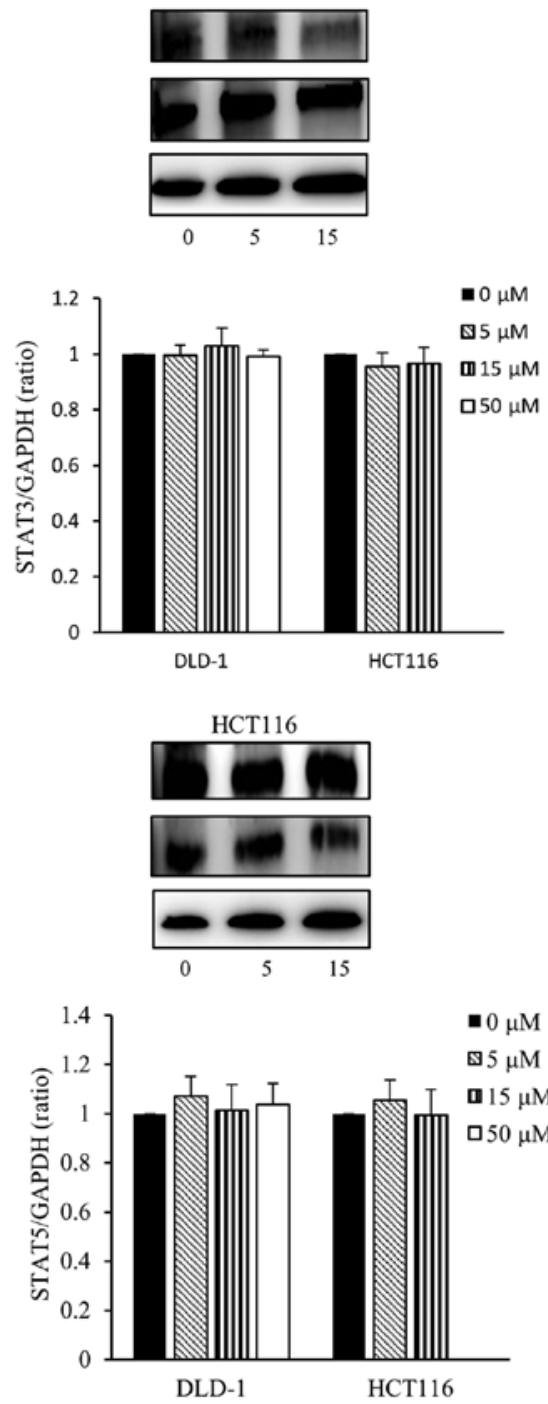

HCT116
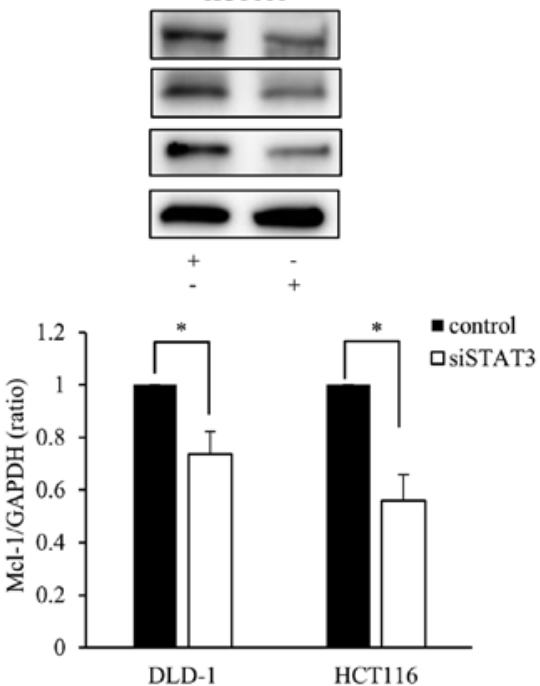

Figure 5. Apigenin inhibits the phosphorylation of STAT3 but does not inhibit the phosphorylation of STAT5 in colon cancer cells. (A) Cells were treated with $0,5,15$ and $50 \mu \mathrm{M}$ (DLD-1) or 0,5 and $15 \mu \mathrm{M}$ (HCT116) apigenin for $24 \mathrm{~h}$ and changes in the expression of total STAT3 and p-STAT3 were measured by western blotting. Band densities were quantified by densitometry using the Amersham Imager 600 and expressed as p-STAT3/GAPDH and STAT3/GAPDH. (B) Cells were treated with 5, 15 and $50 \mu \mathrm{M}$ (DLD-1) or 5 and $15 \mu \mathrm{M}$ (HCT116) apigenin for 24 h and changes in the expression of total STAT5 and p-STAT5 were measured by western blotting. Band densities were quantified by densitometry using the Amersham Imager 600 and expressed as p-STAT5/GAPDH and STAT5/GAPDH. (C) DLD-1 and HCT116 cells were transfected with siRNA targeting STAT3 for $24 \mathrm{~h}$, following which changes in the expression of STAT3, Bcl-xL and Mcl-1 were evaluated by western blotting. Band densities were quantified by densitometry using Amersham Imager 600 and expressed as Bcl-xL/GAPDH and Mcl-1/GAPDH. GAPDH was used as a loading control. The results are representative of three independent experiments and presented as the mean \pm standard deviation. " $\mathrm{P}<0.05$. p-, phosphorylated; si, small interfering; STAT, signal transducer and activator of transcription. 
A

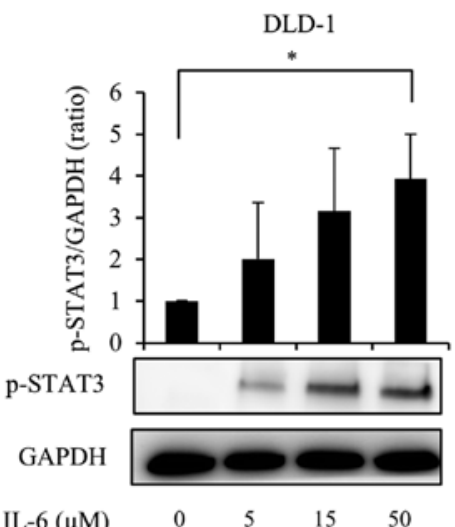

B

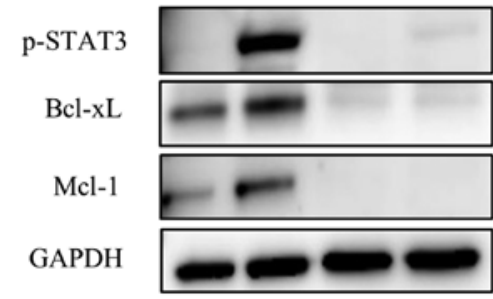

IL-6 $(50 \mu \mathrm{M})$ :

Apigenin $(50 \mu \mathrm{M})$ :

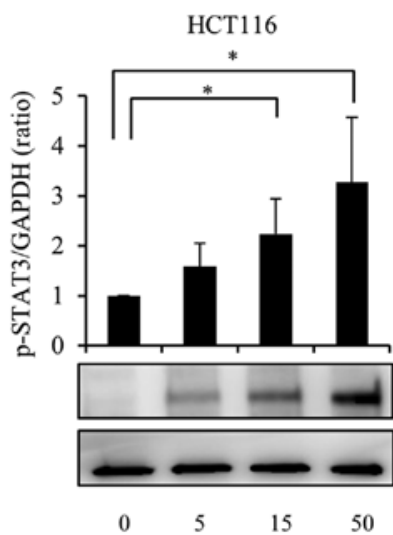

HCT116

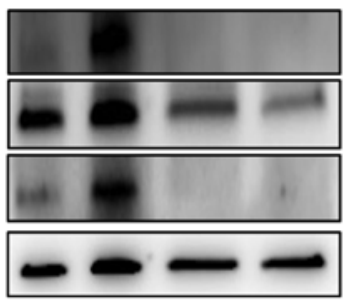

IL-6 $(50 \mu \mathrm{M})$ :

Apigenin $(15 \mu \mathrm{M})$ :
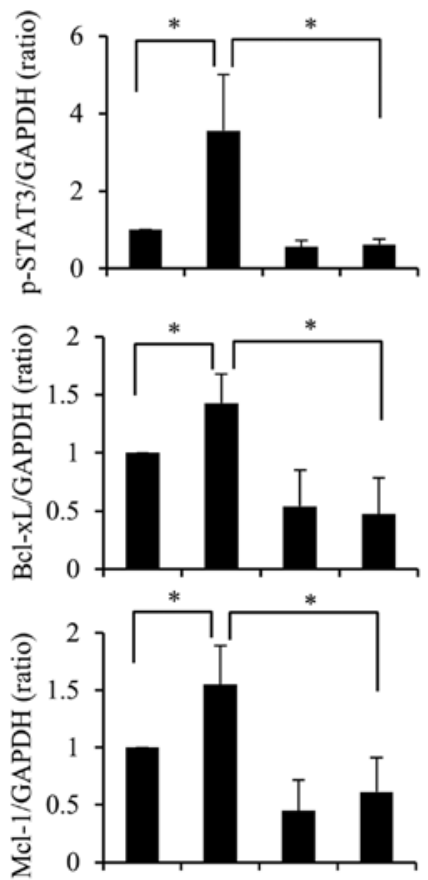

IL-6 $(50 \mu \mathrm{M})$ :

Apigenin $(50 \mu \mathrm{M})$ :
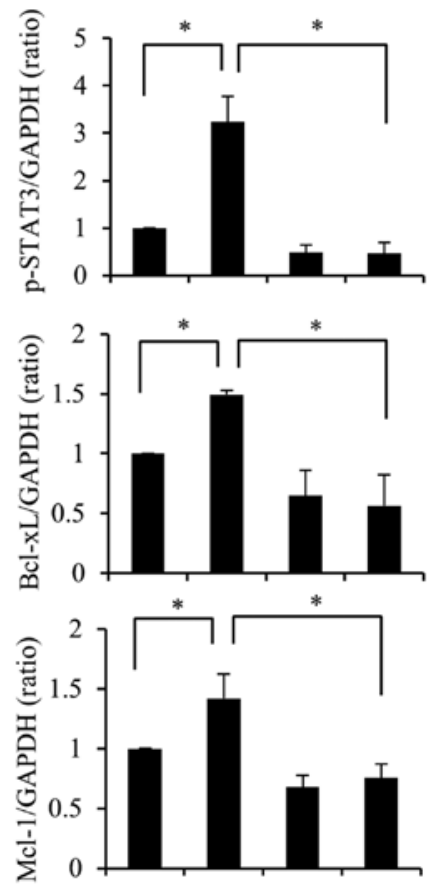

IL-6 $(50 \mu \mathrm{M})$ :

Apigenin $(15 \mu \mathrm{M})$ :

Figure 6. Apigenin suppresses Bcl-xL/Mcl-1 via STAT3 signaling. (A) Cells were treated with 5,15 , or $50 \mu \mathrm{M}$ IL-6 for 48 h. Change in the expression of p-STAT3 was evaluated by western blotting (lower panel). Band densities were quantified by densitometry using the Amersham Imager 600 and were expressed as p-STAT3/GAPDH. (B) Cells were pre-treated with $50 \mu \mathrm{M}$ (DLD-1) or $15 \mu \mathrm{M}$ (HCT116) apigenin for $2 \mathrm{~h}$ followed by $50 \mu \mathrm{M}$ IL-6 for another $48 \mathrm{~h}$. Changes in the expression of p-STAT3, Bcl-xL and Mcl-1 were measured by western blotting. Band densities were quantified by densitometry using the Amersham Imager 600 and were expressed as p-STAT3/GAPDH, Bcl-xL/GAPDH and Mcl-1/GAPDH. GAPDH was used as a loading control. Results are representative of three independent experiments and are presented as the mean \pm standard deviation. ${ }^{*} \mathrm{P}<0.05$.

in colon cancer. The results demonstrated that the simultaneous suppression of Bcl-xL and Mcl-1 strongly reduced cell proliferation and induced apoptosis compared with the suppression of each protein alone. This effect has been 

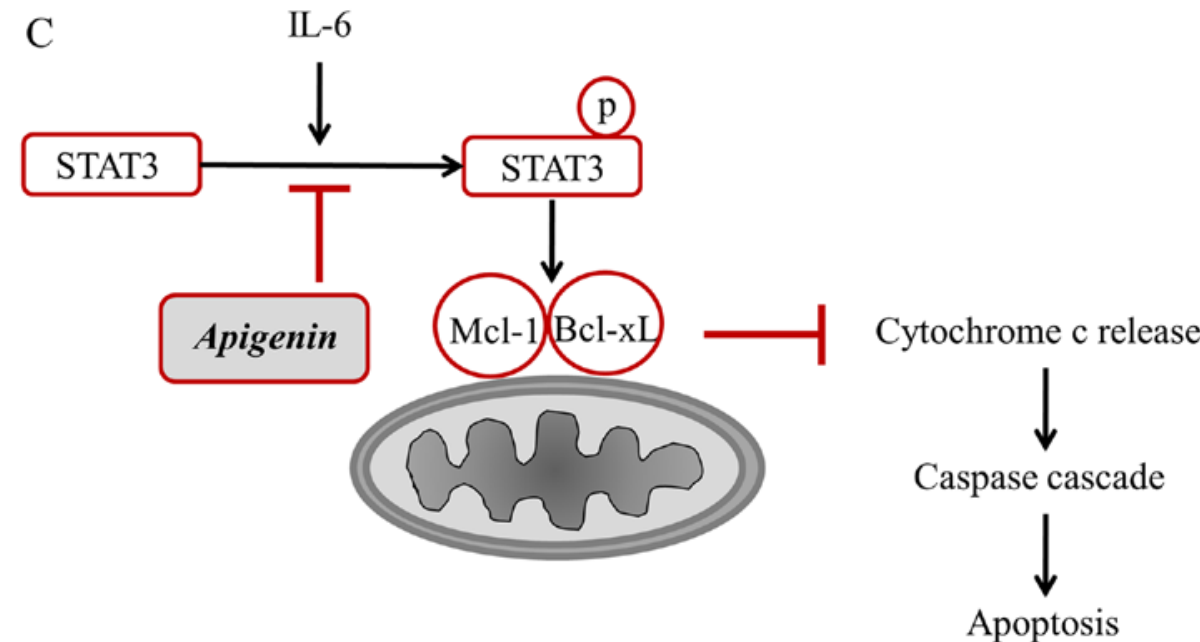

Figure 6. Continued. (C) The mechanism by which apigenin induces apoptosis in colon cancer cells. p-, phosphorylated; si, small interfering; STAT, signal transducer and activator of transcription; IL-6, interleukin-6.

reported in ovarian carcinoma, mesothelioma and pancreatic cancer (34-36), but has not yet been reported in colon cancer. The results of the present study and those of previous studies (34-36) demonstrated that the simultaneous downregulation of Bcl-xL and Mcl-1 induces cancer cell apoptosis.

STAT3 and STAT5 are upstream of Bcl-xL and Mcl-1 signaling (37). Therefore, it was speculated that apigenin suppresses the expression of Bcl-xL and Mcl-1 by inhibiting the signaling of STAT3 and STAT5. The present study demonstrated that apigenin inhibits the phosphorylation of STAT3 but does not inhibit the phosphorylation of STAT5. The marked suppression of Bcl-xL and $\mathrm{Mcl}-1$ expression was observed in the DLD-1 and HCT116 cell lines following STAT3 knockdown. However, STAT5 knockdown did not affect $\mathrm{Bcl}-\mathrm{xL}$ and $\mathrm{Mcl}-1$ expression. These results indicate that apigenin does not induce apoptosis via STAT5 signaling. In addition, the expression of p-STAT3, Bcl-xL and Mcl-1 increased following IL-6 stimulation, but decreased following administration of apigenin. This suggests that apigenin suppresses Bcl-xL and Mcl-1 by inhibiting the phosphorylation of STAT3.

Four colon cancer cell lines were used in the current study. HT-29 and COLO320 are KRAS wild-type whereas DLD-1 and HCT116 are KRAS mutant-type cells. Furthermore, the BRAF mutation status (V600E) of DLD-1 and HCT116 is wild-type and that of HT-29 is mutant (38). Anti-EGFR therapy, which is effective at treating patients with wild-type colon cancer, however, it generally ineffective against KRAS or BRAF mutant colon cancer. However, the results of the present study demonstrated that apigenin exhibited a similar effect in all colon cell lines regardless of KRAS or BRAF status. Therefore, apigenin may be beneficial at treating patients with wild-type and mutant KRAS or BRAF colon cancer.

Apigenin may be an effective method of treating patients with colon cancer; however, the mechanism by which apigenin induces an antitumor effect in colon cancer has not been reported. Shan et al (39) reported that apigenin induces an antitumor effect by inhibiting pyruvate kinase M2 (PKM2) activity via blocking of the $\beta$-catenin/c-Myc/polypyrimidine tract-binding protein 1 signaling pathway. McVean et al (40) reported that apigenin induces $\mathrm{G} 2 / \mathrm{M}$ arrest by inhibiting p34 cyclin-dependent kinase protein expression and activity in a p21-independent manner. However, the results of the current study indicated that apigenin induces an antitumor effect by inhibiting the anti-apoptotic proteins Bcl-xL and Mcl-1 via the STAT3 signaling pathway. This suggests that apigenin acts on various pathways and may therefore be developed as a novel treatment for colon cancer. Furthermore, it was confirmed that Bcl-xL and Mcl-1 are strongly expressed in more advanced colon cancer by immunostaining. This suggests that apigenin may be effective at treating patients with advanced colon cancer.

In conclusion, the results of the current study demonstrated that apigenin induces apoptosis by two anti-apoptotic proteins, Bcl-xL and Mcl-1, via the STAT3 signaling pathway in colon cancer cells. It was also demonstrated that the simultaneous suppression of Bcl-xL and Mcl-1 induces strong apoptosis in colon cancer cells. These data suggest that Bcl-xL and Mcl-1 are important therapeutic targets in colon cancer and that apigenin may be developed as an effective therapeutic agent for colon cancer by simultaneously suppressing the expression of these two proteins.

\section{Acknowledgements}

The authors wish to thank Nagoya City University for providing valuable proposals and assistance to members of the Department of Gastroenterological Surgery. The authors also wish to thank Seiko Inumaru and Ryoko Hara for providing excellent technical support.

\section{Funding}

No funding was received.

\section{Availability of data and materials}

All data generated or analyzed during this study are included in the current published article. 


\section{Authors' contributions}

HT, HI, YoM and ST conceived and designed the study. NN and TY performed the cell proliferation assay, and analyzed and interpreted the data on cell proliferation. NA and TO performed immunohistochemistry, and analyzed and interpreted data on the protein expression of resected specimens. $\mathrm{KeS}$ and $\mathrm{TH}$ performed western blotting, and analyzed and interpreted data on protein expression and change in cell lines. $\mathrm{KaS}$ and $\mathrm{MH}$ performed apoptosis assay, and analyzed and interpreted data on apoptosis. YuM planned, analyzed and interpreted all the experiments and drafted the manuscript.

\section{Ethics approval and consent to participate}

Ethical approval for the use of human tissue was granted by the Graduate School of Medicine, Nagoya City University (Nagoya, Japan). All patients provided their written informed consent for the use of their tissues.

\section{Consent for publication}

Not applicable.

\section{Competing interests}

The authors declare that they have no competing interests.

\section{References}

1. Siegel RL, Miller KD and Jemal A: Cancer Statistics, 2017. CA Cancer J Clin 67: 7-30, 2017

2. Lee DH, Sung KS, Bartlett DL, Kwon YT and Lee YJ: HSP90 inhibitor NVP-AUY922 enhances TRAIL-induced apoptosis by suppressing the JAK2-STAT3-Mcl-1 signal transduction pathway in colorectal cancer cells. Cell Signal 27: 293-305, 2015.

3. Vo MC, Nguyen-Pham TN, Lee HJ, Jaya Lakshmi T, Yang S, Jung SH, Kim HJ and Lee JJ: Combination therapy with dendritic cells and lenalidomide is an effective approach to enhance antitumor immunity in a mouse colon cancer model. Oncotarget 8 : 27252-27262, 2017.

4. Hail N Jr, Carter BZ, Konopleva M and Andreeff M: Apoptosis effector mechanisms: a requiem performed in different keys. Apoptosis 11: 889-904, 2006

5. Kirkin V, Joos S and Zörnig M: The role of Bcl-2 family members in tumorigenesis. Biochim Biophys Acta 1644: 229-249, 2004.

6. Danial NN and Korsmeyer SJ: Cell death: Critical control points. Cell 116: 205-219, 2004.

7. McDonnell TJ, Troncoso P, Brisbay SM, Logothetis C Chung LW, Hsieh JT, Tu SM and Campbell ML: Expression of the protooncogene bcl-2 in the prostate and its association with emergence of androgen-independent prostate cancer. Cancer Res 52: 6940-6944, 1992.

8. Teixeira C, Reed JC and Pratt MA: Estrogen promotes chemotherapeutic drug resistance by a mechanism involving Bcl-2 proto-oncogene expression in human breast cancer cells. Cancer Res 55: 3902-3907, 1995

9. Peddaboina C, Jupiter D, Fletcher S, Yap JL, Rai A, Tobin RP, Jiang W, Rascoe P, Rogers MK, Smythe WR, et al: The downregulation of Mcl-1 via USP9X inhibition sensitizes solid tumors to Bcl-xl inhibition. BMC Cancer 12: 541, 2012.

10. Takahashi H, Chen MC, Pham H, Angst E, King JC, Park J, Brovman EY, Ishiguro H, Harris DM, Reber HA, et al: Baicalein, a component of Scutellaria baicalensis, induces apoptosis by Mcl-1 down-regulation in human pancreatic cancer cells Biochim Biophys Acta 1813: 1465-1474, 2011.

11. Patel D, Shukla S and Gupta S: Apigenin and cancer chemoprevention: Progress, potential and promise (Review). Int J Oncol 30: 233-245, 2007
12. Shukla S and Gupta S: Apigenin: A promising molecule for cancer prevention. Pharm Res 27: 962-978, 2010.

13. Shao H, Jing K, Mahmoud E, Huang H, Fang X and Yu C: Apigenin sensitizes colon cancer cells to antitumor activity of ABT-263. Mol Cancer Ther 12: 2640-2650, 2013.

14. Turkson J and Jove R: STAT proteins: Novel molecular targets for cancer drug discovery. Oncogene 19: 6613-6626, 2000.

15. Bowman T, Garcia R, Turkson J and Jove R: STATs in oncogenesis. Oncogene 19: 2474-2488, 2000.

16. Xiong H, Su WY, Liang QC, Zhang ZG, Chen HM, Du W, Chen YX and Fang JY: Inhibition of STAT5 induces G1 cell cycle arrest and reduces tumor cell invasion in human colorectal cancer cells. Lab Invest 89: 717-725, 2009.

17. Donato NJ, Wu JY, Zhang L, Kantarjian H and Talpaz M: Down-regulation of interleukin-3/granulocyte-macrophage colonystimulating factor receptor beta-chain in BCR-ABL(+) human leukemic cells: Association with loss of cytokine-mediated Stat-5 activation and protection from apoptosis after BCR-ABL inhibition. Blood 97: 2846-2853, 2001

18. Garcia R, Bowman TL, Niu G, Yu H, Minton S, Muro-Cacho CA, Cox CE, Falcone R, Fairclough R, Parsons S, et al: Constitutive activation of Stat 3 by the Src and JAK tyrosine kinases participates in growth regulation of human breast carcinoma cells. Oncogene 20: 2499-2513, 2001

19. Seo HS, Ku JM, Choi HS, Woo JK, Jang BH, Go H, Shin YC and Ko SG: Apigenin induces caspase-dependent apoptosis by inhibiting signal transducer and activator of transcription 3 signaling in HER 2-overexpressing SKBR3 breast cancer cells. Mol Med Rep 12: 2977-2984, 2015.

20. Cao HH, Chu JH, Kwan HY, Su T, Yu H, Cheng CY, Fu XQ, Guo H, Li T, Tse AK, et al: Inhibition of the STAT3 signaling pathway contributes to apigenin-mediated anti-metastatic effect in melanoma. Sci Rep 6: 21731, 2016.

21. Tomita S, Yamauchi M, Ichikawa K, Mitomi H and Fujimori T: The brand new trend of colorectal carcinoma pathology. Nihon Rinsho 72: 63-70, 2014 (In Japanese).

22. Wang SW and Sun YM: The IL-6/JAK/STAT3 pathway: Potential therapeutic strategies in treating colorectal cancer (Review). Int J Oncol 44: 1032-1040, 2014.

23. Gupta S, Afaq F and Mukhtar H: Selective growth-inhibitory, cell-cycle deregulatory and apoptotic response of apigenin in normal versus human prostate carcinoma cells. Biochem Biophys Res Commun 287: 914-920, 2001.

24. Turktekin M, Konac E, Onen HI, Alp E, Yilmaz A and Menevse S: Evaluation of the effects of the flavonoid apigenin on apoptotic pathway gene expression on the colon cancer cell line (HT29). J Med Food 14: 1107-1117, 2011.

25. Horinaka M, Yoshida T, Shiraishi T, Nakata S, Wakada M and Sakai T: The dietary flavonoid apigenin sensitizes malignant tumor cells to tumor necrosis factor-related apoptosis-inducing ligand. Mol Cancer Ther 5: 945-951, 2006.

26. Lee Y, Sung B, Kang YJ, Kim DH, Jang JY, Hwang SY, Kim M, Lim HS, Yoon JH, Chung HY, et al: Apigenin-induced apoptosis is enhanced by inhibition of autophagy formation in HCT116 human colon cancer cells. Int J Oncol 44: 1599-1606, 2014.

27. Budhraja A, Gao N, Zhang Z, Son YO, Cheng S, Wang X, Ding S, Hitron A, Chen G, Luo J, et al: Apigenin induces apoptosis in human leukemia cells and exhibits anti-leukemic activity in vivo. Mol Cancer Ther 11: 132-142, 2012.

28. Lu HF, Chie YJ, Yang MS, Lee CS, Fu JJ, Yang JS, Tan TW, Wu SH, Ma YS, Ip SW, et al: Apigenin induces caspasedependent apoptosis in human lung cancer A549 cells through Bax- and Bcl-2-triggered mitochondrial pathway. Int J Oncol 36: 1477-1484, 2010.

29. Shi MD, Shiao CK, Lee YC and Shih YW: Apigenin, a dietary flavonoid, inhibits proliferation of human bladder cancer T-24 cells via blocking cell cycle progression and inducing apoptosis. Cancer Cell Int 15: 33, 2015.

30. Zhao M, Ma J, Zhu HY, Zhang XH, Du ZY, Xu YJ and Yu XD: Apigenin inhibits proliferation and induces apoptosis in human multiple myeloma cells through targeting the trinity of CK2, Cdc37 and Hsp90. Mol Cancer 10: 104, 2011.

31. Brunelle JK and Letai A: Control of mitochondrial apoptosis by the Bcl-2 family. J Cell Sci 122: 437-441, 2009.

32. Kelly PN and Strasser A: The role of Bcl-2 and its pro-survival relatives in tumourigenesis and cancer therapy. Cell Death Differ 18: 1414-1424, 2011.

33. Czabotar PE, Lessene G, Strasser A and Adams JM: Control of apoptosis by the BCL-2 protein family: Implications for physiology and therapy. Nat Rev Mol Cell Biol 15: 49-63, 2014. 
34. Brotin E, Meryet-Figuière M, Simonin K, Duval RE, Villedieu M, Leroy-Dudal J, Saison-Behmoaras E, Gauduchon P, Denoyelle C and Poulain L: Bcl-XL and MCL-1 constitute pertinent targets in ovarian carcinoma and their concomitant inhibition is sufficient to induce apoptosis. Int J Cancer 126: 885-895, 2010.

35. Varin E, Denoyelle C, Brotin E, Meryet-Figuière M, Giffard F, Abeilard E, Goux D, Gauduchon P, Icard P and Poulain L: Downregulation of Bcl-xL and Mcl-1 is sufficient to induce cell death in mesothelioma cells highly refractory to conventional chemotherapy. Carcinogenesis 31: 984-993, 2010.

36. Takahashi $\mathrm{H}$, Chen MC, Pham $\mathrm{H}$, Matsuo $\mathrm{Y}$, Ishiguro $\mathrm{H}$, Reber HA, Takeyama H, Hines OJ and Eibl G: Simultaneous knock-down of Bcl-xL and Mcl-1 induces apoptosis through Bax activation in pancreatic cancer cells. Biochim Biophys Acta 1833: 2980-2987, 2013.

37. Buettner R, Mora LB and Jove R: Activated STAT signaling in human tumors provides novel molecular targets for therapeutic intervention. Clin Cancer Res 8: 945-954, 2002.
38. Sueda T, Sakai D, Kawamoto K, Konno M, Nishida N, Koseki J, Colvin H, Takahashi H, Haraguchi N, Nishimura J, et al: BRAF V600E inhibition stimulates AMP-activated protein kinasemediated autophagy in colorectal cancer cells. Sci Rep 6: 18949, 2016.

39. Shan S, Shi J, Yang P, Jia B, Wu H, Zhang X and Li Z: Apigenin restrains colon cancer cell proliferation via targeted blocking of pyruvate kinase M2-dependent glycolysis. J Agric Food Chem 65: 8136-8144, 2017.

40. McVean M, Weinberg WC and Pelling JCA: A p21(waf1)independent pathway for inhibitory phosphorylation of cyclin-dependent kinase $\mathrm{p} 34(\mathrm{cdc} 2)$ and concomitant $\mathrm{G}(2) / \mathrm{M}$ arrest by the chemopreventive flavonoid apigenin. Mol Carcinog 33: 36-43, 2002. 